\title{
The evolution of China's climate change policy: international and domestic political economy and a strategy for working with China
}

\author{
Hongyi Lai
}

\begin{abstract}
For over a decade China has been the predominant carbon emitter in the global economy. It is thus imperative for us to understand the factors behind its climate change policy in the past decades. In the article, the author surveys the evolution of China's climate change policy during 1990-2021 and applies theories from international relations and international political economy to explain it. It is found that (neo-)realism/nationalism and liberalism, two main theories in the field, offer only a partial explanation of China's climate policy. The most effective theory is domestic sources. In particular, leadership power consolidation and a concern with economic growth seem to dictate China's climate policy. The findings point to the analytical utility of domestic political economy in accounting for the climate stances of nationstates. Policy suggestions for external parties to interact with China on climate change are proposed. There the importance of involving China in global action against climate change, as well as the utility of the economy and trade leverage, soft power standing, and the prevention of extreme weather are discussed.
\end{abstract}

Keywords: Climate change, public policy, China, domestic politics, international relations, international political economy.

Note on the author: Hongyi Lai is Associate Professor, School of Politics and International Relations, at the University of Nottingham.

hongyi.lai@nottingham.ac.uk

(C) The author(s) 2021. This is an open access article licensed under a

Creative Commons Attribution-NonCommercial-NoDerivs 4.0 Unported License 
Since 2006 China has surpassed the United States to be the largest carbon-emitting economy in the world. In the following years, China's share in global carbon emission continued to soar from 21 to 27.4 per cent in 2018, whereas that of the United States had been declining steadily from 19.93 to 14.9 per cent, and that of the European Union consisting of twenty-seven member states (EU-27) decreased from 12.4 to 8.4 per cent (Our World in Data 2021). Thus, by 2018, China's carbon emissions (27.8 per cent) far exceeded the combined total of the US and the EU-27 (23.3 per cent), the second and third largest carbon emitters. China's share in the world total carbon emissions is poised to further increase in the coming years. Given China's lion share in global carbon emissions and the pressing need to address climate change, it is thus imperative for us to understand the contour of the change in its climate policy and the underlying factors and to involve China in the global action on climate change.

Targeting policymakers, policy analysts, and political scientists, this article aims to shed light on the political and economic factors underlying the evolution of China's climate change policy during 1990-2021. A comprehension of these factors would not only be useful for them to fashion sound responses but will also enable other scholars and the public concerned with climate change to further their understanding of China's climate policy.

To denote China's climate change policy over the decades, the author will categorise a stance that rejects the urgency for a reduction in carbon emissions to address the imperious consequences of global warming as 'defensive'. The term, which conveys a pro-status-quo stand on climate change, also denotes China's position to defend the entitlement of a nation (in the Chinese case and perspective, a developing nation) to develop their economy despite the fact that this will lead to higher carbon emissions at the national and per capita level. Similarly, a position that entails resistance to international calls for action to reduce carbon emissions will be characterised as 'resistant'. In addition, China's apparent retreat from a position favourable toward collective efforts to address climate change will be coined 'regressive'. On the other hand, when China embraces a programme or pronounces a high-profile goal aiming at peaking or cutting carbon emissions, this will be characterised as a 'progressive' or 'proactive' stance on climate change, respectively. Obviously, these labels can be applied to other carbon emitters. For example, until recent years the climate policy of the United States can be viewed as 'defensive' (in this context, the US defends its entitlement to economic growth despite its status of an advanced economy), whereas that under the Biden administration can be regarded as 'progressive'. However, given the primary focus of this article on China, the characterisation of climate policy of other nations over recent decades is beyond the scope of this article. Given the limit on the length of an article and given the voluminous debate on the responsibilities of developed and developing nations for climate change and for carbon emission, the 
author has no intention to arbitrate on this debate. The key focus of this article is to explain the variation in China's stance on climate change over the past decades. It is simply assumed in this article that limitation and reduction in carbon emissions by any nation, developed and developing alike (characterised as 'progressive' or 'proactive' stance on climate change), will help combat climate change and will be hugely beneficial to our planet.

Overall, before 2009 especially 2006, China's climate policy remained rather defensive. Specifically, during 1990-2005 China largely ignored the pressing nature of climate issues and, instead, argued for the urgency of economic development. From 2006 to 2008 China started to soften its resistance to climate issues and acknowledged the negative effects of climate change. This adjustment continued during 2009-11, when China refused to accept internationally binding commitments while announcing its voluntary efforts to reduce carbon intensity. Similarly, climate policy under Xi has experienced ebbs and flows. Xi marked his arrival on the global stage of climate negotiations by putting up an overtly assertive and defensive posture during 2012-14. He dramatically reversed this stance in the subsequent period of 2015-19 by claiming a moral high ground of international leadership. Nevertheless, during 2020-1 the unfolding of heavy industrial and carbon-intensive projects seemed to suggest Xi's retreat from this proactive position on climate issues, despite his public unfolding of a progressive goal.

This article aims to offer an empirical review of the changes in China's climate change policy since 1990. It offers an original and theoretically based interpretation of the change in China's climate policy. Main theories in international relations (IR) and international political economy (IPE), as well as the domestic political economy theory, are applied to explain China's stance over the last three decades. Overall, (neo-) realism/nationalism and liberalism, two main theories in the field, offer only a partial explanation of China's stand. The most effective theory is domestic sources.

This article is organised in the following way. In the first section, the existing literature on China's climate change policy is briefly outlined and reviewed. This is followed by an assessment of the main theories in IR and IPE and their relevance to the case of China's climate change policy. In the subsequent section, China's climate change policy from 1990 to the present will be examined and its main stance and shifts will be identified. The three main theories are applied and their explanatory power for the change in China's position is assessed.

In the final section, building on the preceding analysis of the grave challenges from climate change in China in 2020 and on the findings of this study, this article also suggests a pragmatic strategy for engaging China in the global climate talks and rewarding it appropriately for its positive contribution. This policy-related discussion is relevant, as this article is submitted to a series of special editions of the Journal of 
the British Academy on topics broadly related to climate change. These special editions are related to the Academy's wider work in the area and the debates leading up to and out of the 26th UN Climate Change Conference of the Parties (COP26) in Glasgow hosted by the UK in October and November 2021, as well as the Fifteenth meeting of the Conference of the Parties to the Convention on Biological Diversity (COP15) in Kunming, China in October 2021. The author argues that climate change remains one of the few bright spots where China and the rest of the world could work together constructively for the fate of mankind. It is in China's interest to sustain its proactive stance to fight climate change. It is also in the global and especially British and European interests to encourage China's endeavours on climate change.

\section{The existing literature on China's climate change policy}

The existing literature on China's climate change policies investigates the following issues: economic and technological studies of China's energy consumption and carbon emissions and reduction, as well as the evolution and underlying causes of China's climate change policy. These two streams of studies will be reviewed, with heavy attention to the second stream, as it relates closely to the topic of this article. ${ }^{1}$

\section{Economic and technological studies of energy use and carbon emissions and reduction}

The first stream of literature consists of two inquiries. The first inquiry focuses on the factors that shape energy consumption, demand, and carbon emissions in China. One typical approach is econometric analyses of carbon emissions and energy consumption in China over the past decades, or across its localities such as provinces or major cities (Dhakal 2009, Yu 2012). Using Kaya decomposition approaches, researchers have suggested that underlying drivers of China's carbon emissions are determined by the carbon and energy intensity of its economic growth (Ma et al. 2019). Relevant factors also include industrialisation, urbanisation, energy mix, and final consumption rate (Dong et al. 2018, Ma et al. 2019). Scholars explore the linkage between carbon emissions and economic development (Zhang \& Cheng 2009). They also disagree and debate over the effects of China's climate change policy on peaking of carbon emissions in 2030 (Elzen et al. 2016, Zhang et al. 2016). Other studies also

${ }^{1}$ This article makes use of estimates on China's carbon emissions compared to other major economies, such as those by environmental scientists and economists, such as Myllyvirta (2019) and Spracklen (2016), or those by institutions or internet platforms, such as World Resources Institute $(2014,2017)$ or Our World in Data. They are not covered in the literature review as they are not concerned with China's climate policy. 
examine China's energy demand and sources as well as their prospects (Lai \& Warner 2015a, 2015b, Thomson \& Boey 2015). These studies offer a diagnosis of the patterns of energy production and demand and of carbon emissions, as well as the underlying economic causes. It serves to illustrate the technological possibilities and constraints in China's responses to climate change.

The second inquiry is on the technological and economic measures China has taken or could take to reduce carbon emissions. It surveys and proposes the state's initiatives to reduce carbon intensity and restrain carbon emissions (Wang et al. 2012, Woetzel et al. 2020) and assesses the effectiveness of these policies (Chen, Y. 2012, Wang et al. 2012). Nevertheless, rather than exploring the political causes of China's climate policies, the focus of these studies is on the technicality and effectiveness of these policies, which is obviously important once China has made commitments to address climate change.

\section{Evolution and causes of China's climate change policy}

The studies closest to this article are those examining and explaining China's climate change policy. They purport to review the changes in China's climate change policy in the past two decades and reveal the factors that accounted for the evolution of the policy. While the studies on this topic are relatively limited in number, most of the authors were scholars in social sciences, such as political science and law. Heggelund (2007) examined the relative weight of domestic and external factors. He suggested that China's climate change policy was shaped by the following factors in order of importance: energy demand to sustain China's rapid growth, vulnerability to climate change, material benefits from participating in clean development mechanism (CDM) projects, international pressure, and global climate change. In another study published about the same time, Lewis (2007) argued that domestic bureaucratic advocacy and international pressures combined to produce adjustment in China's formerly obstinate climate stance. An example of international pressure was a shift away from the defensive position on climate change by some forest-rich developing countries such as Brazil to claim aid from developed nations. A third study argued that the change in China's climate policy could best be explained by the advocacy coalition framework (ACF). This argument emphasised the role of scientists and scholars outside the bureaucracy who were advising the government, and their beliefs, and technical information in shaping China's climate policy during 1988-2013 (Stensdal 2014). A fourth study also published around 2007-8 pointed to the high relevance of enlightened pragmatism and domestic politics in moulding and changing China's climate change policy. It was argued that Beijing would be persuaded not by moral obligation, but by concerns with public health, domestic instability arising from climate change 
consequences, and decreasing costs in the wake of improved technology and global image (Wiener 2008). One of the most in-depth studies in this stream was Chen G.'s (2012) book on China's climate change evolution. Echoing the above studies and supplying in-depth analyses, he postulated that a more diversified climate policy process featuring the involvement of bureaucratic players, non-governmental organisations (NGOs), and international pressure, as well as concerns with energy security, had resulted in an adjustment in China's climate policy from resistance to acceptance of international obligation. In his words, 'in response to rising international pressures and domestic energy security issues, and attracted by lucrative carbon businesses and a clean energy market, the regime shows some sort of better-than-expected flexibility and shrewdness in coping with the newly emerged challenges' (Chen G. 2012: xii). One of the latest studies of China's climate policy focused on central-local governmental interaction. Zhang et al. (2019) concluded that the recentralisation of climate policymaking by Xi Jinping, the Chinese top leader, created short-term benefits as well as long-run uncertainty and risks for climate policy implementation in China.

Taken together, this stream of literature tends to incorporate both domestic and international factors in explaining the change in China's climate change policy. The domestic factors include energy security manifest in the stable energy supply needed for sustained economic growth; bureaucratic players, especially those speaking out for a proactive stance in climate policy and central-local interaction; scientists and academic advisers to the government; and vulnerability and public health issues in climate change. The most prominent international factors included the international pressure for climate action, especially from the developed world and NGOs, followed by the shift in the stand toward the developed world by some large developing nations such as Brazil or a group of developing nations. The other international factors included the economic benefits of participating in projects related to climate change, such as CDM, and the global perception of China as acting responsibly or irresponsibly on climate change. These studies tended to conclude that the relative strengths of domestic and international factors created pulls and pushes, resulting in China's eventual climate policy. Meanwhile, domestic factors tended to take precedence over international ones. Nevertheless, it is worth noting that the input from NGOs and scientific advisers alone, as emphasised by Lewis (2007), Stensdal (2014), and Chen G. (2012), seems to increase over the years. As such, it will not suffice to explain the ebbs and flows of China's commitment to address climate change. In addition, the centrallocal dynamics adds nuance to China's implementation of climate policy, instead of dictating it, given China's unitary and centralised structure of the party-state.

This study will expand on the insights from this stream of the literature while pushing for a more theoretical interpretation of China's climate change stances from the 1990s to the present time. Specifically, this study will make the following contributions to the 
existing literature. First, it updates the analysis of China's climate policy to that under Xi's leadership (that is, from 2012 to 2021), thereby extending the analytical interpretation of China's climate action to the most recent twelve years when China has been a predominant carbon emitter. In contrast, most academic studies covered China's climate policy mostly up to 2008. Second, this study will advance the theoretical interpretation of China's evolving climate policy during 1990-2021 by applying three main theories in international political economy and assessing their validity and relative explanatory power. That is what the existing literature has largely failed to do. In addition, it presents a domestic political and economic explanation drawn from analysis of the linkage of China's foreign policy with internal sources from the 1950s to the 2000s (Lai 2010). The explanatory power of this domestic sources theory will be tested in the context of the evolution of China's climate policy. Sources of information come from news reports, policy reports, and academic studies. In particular, this study makes frequent use of established and detailed accounts of China's climate policy by journalists such as Hollingsworth (2017) and scholars such as Chen G. (2012) and Heggelund (2007), policy analyses on China's climate stance, and estimates on China's energy profile, carbon emissions, and renewable energy.

\section{IR and IPE theories and the author's explanation}

Before the author proceeds to the presentation and analysis of China's climate change stance, it is helpful to review the main theories in international relations (IR) and international political economy (IPE). They could provide a relevant theoretical tool for our understanding of China's evolving posture on climate change. The following three schools seem the most relevant to the stands on climate change adopted by nationstates: namely (neo-)realism/nationalism, liberalism, and domestic political economy (DPE). Each school offers a different interpretation of the logic of nation-states' behaviour in global affairs.

\section{(Neo-)realism/nationalism}

(Neo)-realism/nationalism is a short-hand reference to realism, neo-realism, and nationalism. This school has been the mainstream theory and arguably the dominant one in IR and IPE for decades. This school maintains that nation-states are the central players in IR and IPE, despite globalisation and intensified economic and social links between nation-states. It submits that nation-states are the most powerful connector between power and wealth, and that they exert the greatest impact on power and are the ultimate guarantor of national wealth (O'Brien \& Williams, 2016: 8-9). This 
school perceives relations between nations as filled with constant rivals and measured by relative gains. Scholars of this school agree that national interests should be a good standard in formulating national foreign policy, including climate policy. They also concur that the power of the nations is the most immediate and effective basis for advancing and protecting national interests and that the state, instead of markets, should dictate foreign policy (Gilpin 1987: 31-3).

There is a subtle distinction between neo-realism and realism/nationalism. The latter holds that the yearning for power (control or leverage over other states) arises from human nature. It posits that nation-states would strive for power within international affairs. On the other hand, neo-realism believes that the lack of an effective world government in the international system (coined world anarchy) causes nationstates to seek power to protect themselves. In particular, offensive realism, a sub-school of neo-realism, perceives a chaotic and highly insecure international system and argues that the best means to the survival of nation-states is to obtain the most power possible (Mearsheimer, 2001: 21-2).

Translating into climate change policy, (neo-)realism/nationalism will predict an inherent struggle between nations, each striving to take a stance on the issue best suited to its national interests. In particular, neo-realists postulate that nations are primarily concerned with relative gains and see that benefits from climate action will take up to a century to materialise (Purdon 2017). According to (neo-)realist logic, each nation may thus avoid shouldering a big responsibility for carbon reduction, would rather see other nations taking on a greater duty, and would avoid adjusting their policy and fighting against climate change due to the perceived prolonged pain of economic slowdown. This school would thus predict that China would not act on climate change as it does not immediately affect its survival and that it will prioritise its wealth and power over action on the climate issue. Worse, China could act as a freerider, passing the buck to the other nations, or will use its power to pressure less powerful nations to act against carbon emissions.

\section{Liberalism}

The other prominent school of theories in IR/IPE is liberalism. It believes that individuals and states are rational and have sound reasoning toward cooperation. It highlights the growing importance of free trade and capital mobility, as well as an increasing role of firms, NGOs, international organisations, and even activists in global affairs (Gilpin, 1987: 26-8, O'Brien \& Williams, 2016: 20). According to two of the leading advocates of this school, inter-state interaction is moving away from the highly competitive and potentially deadly and mutually destructive realm of military rivalry toward less deadly and more cooperative and beneficial realms of economic, 
social, and environmental areas of concerns. Interdependence among states is rising. It is in the interests of nation-states to work out international regimes to tackle issues of common concern and to contain destructive competition and conflict (Keohane 1984, Keohane \& Nye 2012).

Climate change has been regarded by liberals as an issue affecting the future of human civilisation. No nations would be spared from the catastrophic outcomes of global warming, such as calamitous weather and a rising sea level. Working together with other nations to address this pressing global problem is in the interests of all nations. According to Keohane (1984: 244), even without the leadership of a hegemon such as the United States, international regimes and institutions can foster international cooperation by providing a convenient platform to bring nations together, supplying necessary information and reducing information costs, facilitating agreements, decentralising their enforcement, creating linkage across issues, and reducing transaction costs. Liberal scholars would thus predict that out of their self-interest nations would participate actively in the global action to tackle climate change and would eagerly seek ways to reduce carbon emissions. Keohane (1984: 252-3, 258) proposed what I coin a liberal yet pragmatic argument on international cooperation. He argued that a small number of developed nations shared common interests over a range of issues and that they could work together to address a host of major global issues. This claim seemed to apply to most of the developed nations, especially the European Union, and with some exceptions to the United States on climate change. Echoing Keohane's argument, Victor (2006) even suggested that flexibility in policy choice and international treatments and unconventional wisdom might be needed in forging substantial international efforts on the climate issue. He proposed that a forum of leaders of twenty key nations on climate change would overcome the issue of diverse interests among nearly 200 nations and areas on the issue and could take the lead in global climate action.

\section{Domestic political economy (innenpolitik)}

The third theory relevant for the national stance on climate change is domestic political economy. This school holds that domestic political and economic coalitions, the articulation of their interests in the policymaking process, and leadership are the key factors that shape the climate change of nations. In the first book-length investigation of the domestic sources of China's foreign policy, the author (Lai 2010) proposed that domestic political and economic regime, political security, vision and skills of leaders, and the decision-making process help drive foreign policy. Foreign policy is formulated to serve the interests of the regime, the ruling coalition, and the top leader. This approach is applied to China's inauguration of the Belt and Road Initiative (BRI). 
It has been argued that the BRI aimed to help the heavy industrial sectors dominated by state firms to find outlets for their surplus product, to speed up growth in the western region which possessed these sizable sectors, and to ensure a steady supply of energy to power China's economic growth (Lai 2021). China's climate policy may be conditioned by two domestic factors. The security of the top leader affects China's external posture. When a leader is busy with consolidating his power, he may be reluctant to make international concessions, as doing so would be perceived as weak and would undermine political support at home. In addition, since 1978, the ruling party in China (that is, the Chinese Communist Party) has viewed economic growth as a key basis for its political legitimacy and has thus given it heavy political attention (Lai 2010).

\section{Other theories}

Marxist scholars have offered a critical yet rather comprehensive perspective on capitalism and the environment. They attribute environmental degradation and climate change to the capitalist restless pursuit of profits and over-accumulation (Gills 2010). The Chinese state is also seen by historical materialist scholars as following the path of capitalism by promoting exports, attracting foreign investment, and tolerating capitalist extraction from workers through less-than-ideal working conditions as well as inequalities (Hardy 2017). Nevertheless, this approach will not predict the ups and downs of China's climate policy. It is thus not adopted in this analysis.

According to constructivist theory (Wendt 1999), national identity is critical in understanding the perceived national interests and actions of a nation-state in the world. From 1990 to 2021, China identified itself with developing and emerging economies, such as India, South Africa, and Brazil, and had been emphasising its rights to economic development and growth in carbon emissions in international climate negotiations. Although this identity has remained unchanged, China's climate policy has undergone considerable changes. Thus constructivism seems to have limited utility in accounting for the vicissitudes of China's climate stance and will not be included as a theory to be tested below.

In the following section, the author will review the evolution of China's climate change policy since 1990. It is found that the domestic political economy provides the best explanation of the apparent change in China's stance on climate change, even though other factors might have been relevant to some extent. 


\section{Explaining the evolution of China's climate change policy during 1990-2011}

The existing literature, especially that on the evolution of China's climate policy, covers mostly the period up to 2008. This study will cover the period of 1990-2021. In the following two sections, China's climate policy during 1990-2011 and that in the era of Xi Jinping from 2012 to 2021 will be examined, respectively. In both sections, the author will describe the main contents of China's climate policy in each of the six periods of 1990-2021 (these periods will be outlined shortly). He will then examine the main variables helping to explain the features of China's climate policy of each period and, if relevant, the change from those in the previous period. The main features of China's climate policy are summarised in the second and third rows in Table 1.

Six main periods in China's climate policy from 1990 to 2021 can be identified by the main features of China's climate policy. During 1990-2005 (Period 1) China's position could be viewed as strictly defensive and resistant toward the climate change argument and the prescribed reduction in carbon emissions. In the ensuing period of 2006-8 (Period 2), China started to be responsive to climate issues. It publicised its international commitments in restraining carbon emissions in 2009-11 (Period 3). However, China's stance was still viewed as insufficient by the climate change advocates in the developed world, especially the EU, and thus tension between both sides simmered. Their clash culminated in the wake of the 2009 Copenhagen summit, to be detailed below. From late 2012 onwards, China's climate policy has entered the era of Xi Jinping. In the following period of 2012-14 (Period 4), China appeared uncompromising in global climate talks in defending the rights of developing nations to develop. This defensive stand was dramatically reversed between 2015 and 2019 (Period 5) when China signed and upheld the Paris agreement. At the latest period starting from 2020 (Period 6), China seemed to pull back from its proactive stance by embracing carbon-intensive developmental projects at home.

In analysing these six periods, the author will draw upon the aforementioned in-depth and well-grounded studies on the evolution of China's climate policy during the 1990s and the 2000s. The author is aware of the complexity of China's climate policy as uttered by Chen G. (2012: x) as follows:“To understand China's climate change policy is not easy, as the country itself is a paradoxical factor in the global climate political economy.' Nevertheless, this exercise is worthwhile, as it enables us to gain a valuable glimpse into the evolution of China's stance regarding climate change, as well as the key variables that condition China's endeavour.

In applying the nationalist, liberal, and innenpolitik perspectives to the main causes of the ebbs and flows of China's climate stance, the following factors are highlighted in each period of China's climate policy. The first factor is the degree of nationalism 
in China's stance on the climate issue. When China argued for development rights, this stand fitted the (neo-)realist/nationalist perspective on international affairs. It will be seen as validating the (neo-)realist/nationalist explanation. The second factor is the global pressure on China to act on the climate issue. This factor was revealed to be relevant in several existing studies (Lewis 2007, Chen G. 2012). To a large extent, this factor is in line with the liberal argument reviewed above in two ways. First, the liberal school argues that international cooperation is possible over global issues. Second, as the liberal pragmatic view uttered by Keohane (1984) and Victor (2006) indicates, a feasible way to address pressing global issues is to have a small number of influential nations work together and forge coordinated action. China would thus be a critical member of this small but influential climate coalition. The third and fourth factors relate to the innenpolitik perspective. To be specific, the third factor is domestic leadership, which indicates whether the top leader has consolidated his power or not. This variable is derived from the author's finding (Lai 2010): When a new leader is busy with consolidating his power, usually in the initial years of his assumption of the post, he would appear nationalistic to shore up political and popular support. However, after he has consolidated his power, he would be more willing to be cooperative in international negotiations. The fourth variable is the domestic concern with economic growth (ranging from extremely high to moderate), depending on the growth rate in China. As expounded in the existing study (Lai 2010, 2021: 324), economic growth constitutes the primary basis for China's leader to claim political legitimacy. A sluggish growth rate would usually cause the leadership to be gravely concerned with economic growth, whereas a double-digit annual growth rate would reduce their concern to a moderate level.

If any of these factors (say, international pressure) is correlated with a change in China's posture on the climate issue, the concerned theory (in this case, the liberal school) would then be deemed as effective in explaining China's climate policy in this concerned period. In Table 1, three sets of variables used to explain China's climate change policy are summarised. Those variables that are best at explaining the policy are highlighted in bold, and those variables that are partially correlated with China's climate stance are indicated in italic bold.

\section{0-2005: utterly defensive}

In the 1990s, China set up inter-ministerial coordinating bodies to manage its climate policy. In 1990, the National Climate Change Coordination Leading Small Group (CCCLSG; guojia qihou bianhua duice xietiao lingdao xiaozu) was established as the highest-level climate policy-making body to coordinate climate policy and efforts among ministries. The CCCLSG was presided over by the National Development and 
Reform Commission (NDRC). Before 1998, the China Meteorological Administration (CMA) was entrusted with coordinating climate change policy and representing China on the Intergovernmental Panel on Climate Change (IPCC). Since 1998, the NDRC has assumed a prominent role in China's climate policy. A Climate Change Office was set up within the NDRC in 1998 to provide secretarial assistance to the CCCLSG (Heggelund 2007: 168). After the administrative restructuring in 2003, the Energy Bureau in the NDRC took charge of China's energy policy (ibid: 172). The other major bureaucratic players in China's climate policy included (1) the Ministry of Foreign Affairs (MFA) which seemed to have taken a foreign policy stance on climate change similar to the NDRC, and (2) the Ministry of Science and Technology (MOST) with responsibility for research and technological transfer regarding climate policy (ibid: 173). Both ministries were members of the CCCLSG.

As early as 1990, China's ministries started to formulate a stance toward environmental issues including climate change that was later known as 'common but differentiated responsibilities' (CBDR). In 1990, at a meeting the Foreign Ministry, the State Planning Commission (SPC), the predecessor of the NDRC, the National Environmental Protection Agency (NEPA), and State Science and Technology Commission (SSTC) formulated the following guidelines for international environmental negotiations: economic development should be integrated instead of sacrificed for the environment; developed nations were historically responsible for the damage to the environmental and greenhouse gas emissions, and therefore should provide resources for implementation of international treaties and should provide developing nations with relevant technology at a below-market price; no country should meddle with the decision by other countries to use natural resources (Economy 1998: 271-2, as cited in Chen G. 2012: 5-6). Later, the spirit of these guidelines, known as the CBDR, was included in the United Nations Framework Convention on Climate Change (UNFCCC) of Earth Summit in Rio de Janeiro, 1992. For years it was the cornerstone of the stance by developing nations toward climate change. The Kyoto Protocol passed in December 1997 obliged developed nations to cut their greenhouse gases but exempted developing nations from this burden. The protocol provided handsome rewards for developing nations, especially China with funds to improve its environmental protection during development through the CDM funds and projects, which will be elaborated below. China's pioneering role in germinating the CBDR and in defending the rights to development for the developing countries earned it legitimacy and reputation within the developing world (Chen G. 2012: 6-8).

In addition to CBDR and in line with its 1990 guidelines, China declared its refusal to accept mandatory carbon reduction and third-party monitoring. During the negotiation of the Kyoto Protocol in 1997, China suggested not committing to 


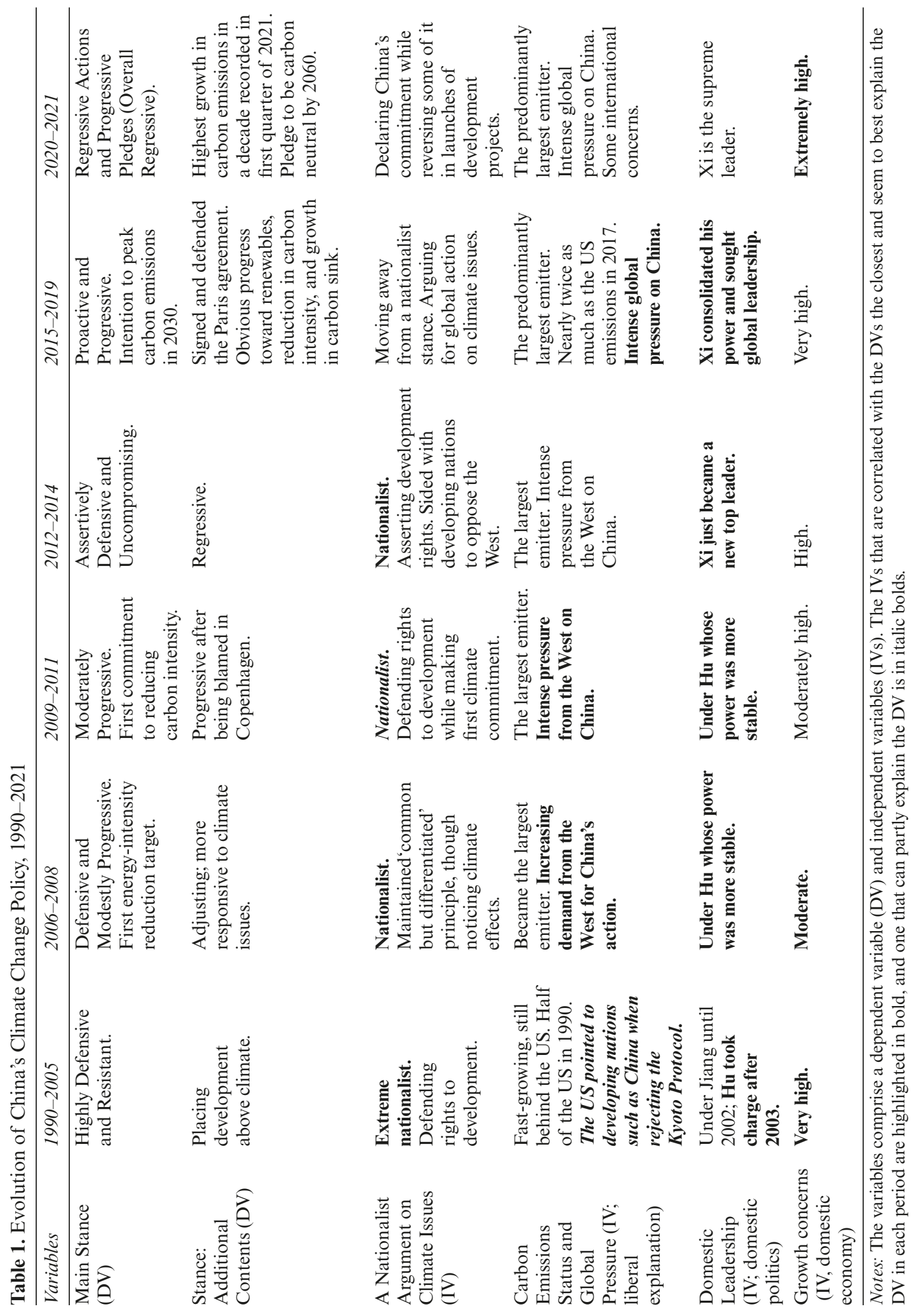


carbon reduction until it reached a 'medium level of development' around US $\$ 5,000$ (ibid: 178). Nevertheless, it had actively been involved in CDM projects. In 2004, a Designated National Authority (DNA) was established within the NDRC for the management of the CDM projects. By the end of 2006, 255 projects had been approved (ibid: 179-82). China did utilise CDM to access technology to help develop its domestic renewable technology and catch up with the advanced economies (Lewis 2012). However, as illustrated by Thomson and Boey (2015), China's energy has been drawn predominantly from coal, a primary energy source that produces most carbon emissions, and this will remain the case in the foreseeable decades. Thus, overall, China's attitude toward the Kyoto Protocol could be characterised as support for it without having committed to mandatory cuts in carbon emissions, while trying to benefit from the climate change funds and access to renewable energy technology.

As just discussed, during this period, China adopted a highly defensive posture toward climate issues. During this period, China's carbon emissions were rapidly expanding, though still behind those of the United States. In 1990, China emitted an equivalent of half of the amount of carbon dioxide by the US. During this period, the main demand for China to act on climate change came mainly from the United States, especially when the latter was reluctant to sign on to the Kyoto Protocol. Turning to domestic factors, China's frontline top leader Jiang Zemin wholeheartedly embraced the emphasis on GDP growth laid down by Deng Xiaoping in his governance of the nation since 1992. Deng was the paramount leader in China from 1978 to $1994 .^{2}$ Anything which seemed to impede China's growth, such as climate commitments, would be perceived as politically unacceptable. Jiang remained the top frontline leader until 2002. During 2002-5, Hu Jintao succeeded Jiang to be China's frontline top leader. Needing to consolidate his power within the party-state during these years, $\mathrm{Hu}$ had largely inherited the single-minded focus on GDP-based economic growth without deviation. In this period, China was the international spokesman for the nationalist position on climate change. It vigorously defended the rights of developing nations to economic growth, urged the developed world to shoulder the bulk of responsibilities over carbon reduction, rejected the demand for it to cut back carbon emissions, and championed the CBDR principle.

\footnotetext{
${ }^{2}$ Deng died in 1997. However, during 1994-7, his final years, Deng's poor health prevented him from supervising China's policies. Jiang was thus in charge.
} 


\section{6-8: defensive and modestly progressive}

The turning point for China's change in its CBDR came around 2006 and 2007. In 2006, China published its 11th five-year plan (FYP) covering the period 2006-10. For the first time in history, its FYP included a target regarding energy consumption which would reduce carbon intensity and the growth in carbon emissions. This FYP mandated a 20 per cent reduction in energy intensity: namely, energy consumption per unit of GDP in five years. The target might be included for multiple reasons. First, it was in line with the 'scientific outlook on development', a concept on economic development proposed by President Hu Jintao. This notion of development departed from the previous simplistic emphasis on GDP growth and heeded the environment, as well as the welfare and well-being of the population. Second, China's carbon emissions had been growing rather rapidly in the previous decade, registering 6 per cent a year during 1994-2005. In particular, China's carbon emissions from the combustion of fossil fuel grew at an alarming 15.6 per cent a year during 2002-5 (Zhang et al. 2009: 151). Despite China's refusal to admit it, the increase in China's carbon emissions far surpassed the other two largest carbon emitters: namely, the United States and India in Annex I in the Kyoto Protocol (ibid: 154-5). Third, by introducing this mandatory target in energy intensity reduction China aimed to rein in the escalating energy demand and rising energy price and ensure energy security while easing global concerns with its soaring carbon emissions.

China received negative international attention as the largest carbon emitter. In April 2007 the International Energy Agency (IEA) revealed that China could become the world's largest emitter of greenhouse gases as early as 2007 (Chen G. 2012: 9). A month later, the IPCC, the United Nations body leading climate change action, met in Bangkok. Its working group delivered a report recommending a range of tools to contain global temperature rise, including charging polluters up to US $\$ 100$ for each ton of $\mathrm{CO}_{2}$ by 2030. China was regarded by some nations as a major obstacle to the approval of this report (Chen G. 2012: 9). Although being the largest carbon emitter and eager to sustain its rapid growth in the coming decade, China did not want to be an outcast in the global climate talks and be the prime target of sanctions or draconian anti-warming measures advocated by the developed nations.

China's strategy to fend off international criticisms and the potential risks of derailing its domestic growth had been two-pronged. On the one hand, it tried to resist international criticisms and formally uphold CBDR. On the other hand, it stepped up its action to reduce the growth in its carbon emissions by announcing voluntary targets to improve carbon intensity. In 2007, China published the National Climate Change Programme (《中国应对气候变化国家方案》). In this document, the NDRC acknowledged the adverse implications of global climate change as well as the 
difficulties for China to accept the mandatory carbon reduction target, given its heavy reliance on coal as an energy source and its need to develop its economy (Chen G. 2012: 10). In the same year, the National Leading Small Group to Address Climate Change was established. It was headed by Premier Wen Jiabao and his deputies included a Vice Premier and a State Councilor. China also reiterated its energy intensity reduction target in its 11th FYP.

During this period, China's climate stance was defensive. It had largely adhered to the nationalist argument on climate issues by upholding the CBDR. However, China also started to bear the brunt of the international pressure for action, as it eclipsed the United States to be the largest carbon emitter during this period. China's willingness to acknowledge the side effects of climate change had a clear domestic linkage. President $\mathrm{Hu}$ had consolidated his power. In the wake of the SARS outbreak, he proposed a scientific outlook on development and moved the nation away from the simple-minded focus on GDP-based economic development. Meanwhile, China was enjoying phenomenal economic growth. As a result, President $\mathrm{Hu}$ and Premier Wen were not overly concerned with the dampening effect of climate action on China's growth. Being more or less politically secure, nor were they concerned that accommodating international demand for carbon reduction would critically undermine their leadership posts.

\section{9-11: moderately progressive}

The year 2009 seems another replay of 2007 when China took voluntary action to slow down the growth in its carbon emissions. However, later that year it was caught in international controversy, which overshadowed its pledge of action. In September 2009, President Hu delivered a speech at the United Nations. He announced several unprecedented pledges by China regarding containing the growth of carbon emission: (1) to reduce per unit of GDP $\mathrm{CO}_{2}$ emissions by $40-5$ per cent in 2020 compared to 2005; (2) to increase non-fossil fuels in primary energy consumption to 15 per cent by 2020; (3) to increase forest coverage by 40 million hectares by 2020 from 2005 to absorb carbon emission; (4) to develop a green and low-carbon economy and technologies (New York Times 2009).

However, the widely perceived failure to pass a legally binding international accord to combat climate change at the Copenhagen summit in December 2009 placed China in a highly negative international limelight. China and other major developing economies such as India, Brazil, and South Africa, on the other hand, rigorously defended their rights to economic development (Guardian 2009, Independent 2009). Leaders of developed nations such as a senior official from an EU nation and Ed Miliband, the climate secretary of the UK, blamed China for rejecting a legally 
binding target to reduce its rising carbon emissions, thereby derailing the Copenhagen climate summit.

In 2011, China had adopted two responses in the wake of the fiasco at the Copenhagen summit. The first response was the inclusion of three targets concerning energy usage and carbon emissions in its 12th FYP. Unfolded in March 2011 and governing the period 2011-15, the 12th FYP mandated a 16 per cent reduction in energy intensity, raised the share of non-fossil fuel energy in total energy use to 11.6 per cent, and required a 17 per cent reduction in carbon intensity, that is, carbon emissions per unit of GDP. The second and especially the third targets were included in the FYP for the first time, reflecting the urgency for China to showcase its determination to cope with climate change.

The other response was a conditional softening of its long-standing refusal of an internationally binding carbon reduction commitment. In December 2011, at a climate summit in Durban, South Africa, China expressed its willingness to accept a legally binding agreement on carbon emissions reduction as long as developing countries including China were treated differently from rich countries (Hollingsworth 2017). Even though the resistance from China and India toward the pressure from the developed world on carbon reduction prevented any major agreement from being reached then, the parties at the meeting agreed to strive for such an agreement in 2015. This change in the stand was noticeable. Back in 2007, Lu Xuedu, deputy directorgeneral of China's Office of Global Environmental Affairs, declared China's refusal to binding commitments, citing its lack of capability to reduce carbon emissions. This position was visibly maintained by China until 2009 (Hollingsworth 2017).

During this period, China continued to soften its defensive stance on climate issues. It partially embraced the nationalist posture by rejecting international binding commitments, supporting its development rights, and reaffirming CBDR, especially at the internationally watched Copenhagen summit in 2009. However, under intense international pressure, especially backlash from Western Europe, China announced its first international commitment to a reduction in its carbon intensity and to enhance carbon sinks through forestation. A critical cause seems to be the security of the top frontline leader in China. As Hu started his second term as China's frontline top leader, his political status was secure. He could thus afford to accommodate international demand for reasonable action to address climate issues. Furthermore, during this period, through fiscal stimulus, China sustained its high economic growth in the wake of the global financial crisis of 2008. Thus, while $\mathrm{Hu}$ was concerned with economic growth, his concern was not as high as Jiang's during the first period, or in the later period under Xi. 


\section{Understanding climate change policy under Xi Jinping (2012-present)}

\section{2-14: assertively defensive and uncompromising}

The early years of Xi's leadership were marked by an assertive stance to defend China's long-standing position of siding with the developing world and resisting the pressure from the developed world to reduce carbon emissions substantially. China was not afraid to play hard-ball tactics. In December 2012, one month after Xi was inaugurated as the new paramount leader in China, Xie Zhenhua, the top Chinese official on climate policy, spoke to countries in Doha, Qatar, where they met and agreed to extend the expiring the Kyoto Protocol. He coined the developing countries as 'victims of climate change' and declared that developed countries should do more than developing ones. The next year, China and the United States disagreed over whether developed countries should do more in climate action when nations met in Warsaw, Poland. In discussions regarding compensation for countries suffering the most from global warming, the G77 countries and China organised a walkout of 132 developing countries. At the end of the Warsaw meeting, countries agreed to publish their emission reduction contributions in 2015 (Hollingsworth 2017).

Despite the high international demand for China's climate action, Xi's China embraced an assertive, defensive, and uncompromising position on climate issues. The nationalist element was highly visible in China's position. Its characterisation of the developing nations as 'victims of climate change' and its leadership in the boycott of climate talks at Warsaw marked an unapologetic act of nationalism. During this period, China's concern with decelerated domestic growth was high, though probably not as intense as during 1990-2005. The most relevant factor seems to be that Xi had just become the new top leader in China. Newly assuming his post, Xi needed to consolidate his power. For this purpose, he fanned nationalist sentiments in China by championing China's new strength on the world stage. As a result, he did not want to be perceived as too weak and too accommodating to Western demands for climate action.

\section{5-19: proactive and progressive}

In 2015, in formulating the first FYP under his leadership, namely, the 13th FYP covering 2016-20, Xi kept the three important climate-change-related indicators introduced by his predecessor: namely, the reduction in energy intensity, the reduction in carbon intensity, and an increase in the share of clean energy in overall energy consumption. He also continued to further experiments with the green economy. The 13th FYP set a target of reducing China's carbon dioxide intensity by 18 per cent and of reducing its energy intensity by 15 per cent during the five years. These targets 
showcased China's efforts to meet its international commitments to peak its carbon emissions in 2030 under the Paris Agreement on Climate Change. The 13th FYP included a nationwide total energy cap for all energy sources at less than the equivalent of five billion tonnes of coal over the next five years. This cap could be easily achieved thanks to the drastic slowdown in the growth in China's energy usage slowed from 6.4 per cent from 2005 to 2012 to 2.3 per cent annually from 2012 to 2015 . The share of clean energy in total energy use in the 13th FYP was set to increase from 12 per cent under the 12th FYP to 15 per cent by 2020. In December 2016, the 13th Five-Year Renewable Energy Development Plan specified \$373.1 billion (RMB 2.5 trillion) in total investment for a new installed capacity of renewable energy by 2020 , including $\$ 74.6$ billion (RMB 500 billion) for hydropower, $\$ 104.5$ billion (RMB 700 billion) in wind, $\$ 149.3$ billion (RMB 1 trillion) in solar, and additional investments in biomass, power generation, biogas, and geothermal energy utilisation (Koleski 2017: 18). The 13th FYP reaffirmed its backing for the Made in China 2025 initiative, and the latter identified new energy vehicles as one of the ten key sectors the state should support (ibid: 9).

On 30 June 2015, China submitted its Intended Nationally Determined Contribution (INDC), including the target to peak $\mathrm{CO}_{2}$ emissions by 2030 at the latest, lower the carbon intensity of GDP by 60-5 per cent below 2005 levels by 2030, increase the share of non-fossil energy carriers of the total primary energy supply to around 20 per cent by that time, and increase its forest stock volume by 4.5 billion cubic metres, compared to 2005 levels. In December 2016, China joined the Paris agreement, a global agreement to step up action and investment to combat climate change. It maintained its commitment and criticised the Trump administration's withdrawal from the pact in 2017 (Hollingsworth 2017).

Around 2017, China's INDC was rated 'medium', between sufficient and inadequate, by Climate Action Tracker (climateactiontracker.org), the same rating for the INDC as the US, India, Brazil, and EU. In contrast, Australia, Canada, Indonesia, Japan, Russia, South Korea, South Africa, and Saudi Arabia were rated 'inadequate'. In 2020, this website rated China's climate targets as insufficient, and highly insufficient by 2030 , as its rationale and emission trajectory will leave the world's temperature to rise by 3-4 degrees Celsius (Climate Action Tracker 2020).

According to a Chinese governmental source, by 2019, China's climate change action had achieved the following results. Its carbon intensity declined by 48.1 per cent compared to that in 2005, well ahead of its international pledge of a reduction by 40-5 per cent. Besides, non-fossil fuel accounted for 15.3 per cent of energy consumption, up by 7.9 percentage points from 2005, meeting its 15 per cent target scheduled for 2020. In 2018, renewable energy was responsible for 26.7 per cent of the nation's power generation, with 16.9 per cent coming from hydropower, and 9.85 per cent from 
wind, solar, and biomass (Gov.cn, 17 November 2019). Besides, during the 2005-18 period the forest area in China grew by 45.1 million hectares, and its forest stock expanded by 5.1 billion cubic metres, topping the world (Xinhua Net 2020).

In particular, China has made the biggest investment in renewable energy and has built up the largest renewable energy capacity in the world in recent years. This is arguably China's most noticeable action in global climate change. A report on the development of global renewable energy in 2019 captured China's prominence in this sector in the following terms, 'China and other developing and emerging economies accounted for a higher share of total renewable energy investment than developed countries for the fifth consecutive year, and China again had the highest total investment despite a decrease for the second year in a row' (REN21, 2020: 30). In 2019, China invested a whopping US\$90.1 billion in renewable power and fuel capacity, accounting for nearly 32 per cent of the global total. China's dominance in this department remained in 2019, despite its investment falling by 6.0 per cent from 2018, compared to a meagre increase in global investment by 1 per cent during the same period (REN21, 2020: 166, 169). China topped four out of the eight areas of renewable energy capacity being invested. These four areas are solar photovoltaics, wind power, hydropower, and solar water heating capacity. The remaining four areas were dominated by four individual nations (REN21, 2020: 36).

During this period, China's stand on climate issues could be characterised as the most progressive since 1990, despite criticisms. Xi apparently and publicly abandoned the nationalist argument on climate change. He called for and openly embraced global cooperation to combat climate change. His change of heart might have had to do with the continued international pressure, which China had been feeling since the period 2006-8. His active stance also deviated from an apparent domestic concern with noticeably decelerating economic growth in 2018-19 in the wake of the trade war with the United States, the last two years of this period. So the best predictor of this change in China's policy seems to be the security of national leadership. By 2015, Xi had consolidated his power at home. He had the ambition to project China's status as a global leader over issues of global concerns, especially over high-profile issues such as climate change.

\section{0-21: regressive actions amidst progressive moves (overall regressive)}

In this section, three new developments regarding China's stance on climate change will be briefly discussed. The first development was that China is seen as refraining from taking determined actions in climate change due to economic considerations. An analyst raised an alarm over the weakening of Xi's commitments to climate change 
action in his possible attempts to resuscitate an economy severely damaged by the COVID-19 outbreak. Signs of concerns included the cutting of spending on solar and wind power, a surge in funding on coal-fired power plants, as well as expanding unnecessary infrastructure such as high-speed rail, subways, and airports. Furthermore, China seems to be injecting a huge sum of investment into heavy industries that had long suffered from oversupplies of products, such as steel, aluminum, plate glass, and cars (Smith 2020). This concern was echoed by a Reuters report, which cited an analyst from a Chinese official think-tank and took note of the rush toward big projects in certain provinces in China, including the nation's key coal-producing base, that is, Shanxi (Xu \& Stanway, 2020). Analysis suggested that in the first quarter of 2021, China's carbon dioxide $\left(\mathrm{CO}_{2}\right)$ emissions were 5 per cent higher than in 2019, a pre-COVID-19 level, and that China's carbon emissions soared by 15 per cent yearon-year, reaching their fastest pace in more than a decade. Energy demand appeared to sustain its surge in the second quarter of 2021 (CarbonBrief 2021a).

Among the potential causes listed in Table 1, the variable that can best explain China's retraction from its progressive climate course is domestic economic concerns. The COVID-19 outbreak has derailed China's decent economic growth and might have even caused a downturn in the first half of 2020, one of the lowest growth rates for decades in China. This temporary economic recession raised an alarm for the Chinese leadership. To sustain his legitimacy and fend off political, economic, and social problems, Xi reverted to the conventional tools of starting investment-intensive and even energy-intensive projects to stimulate the economy. Thus domestic political economy has driven China's deviation from its climate commitment.

The second development is devastation in China from extreme weather associated with climate change. In 2020, unprecedented floods in numerous river basins wreaked havoc on multiple regions in China. During June-mid-July, the rainfall in the middle and lower Yangtze basin reached the highest amount on record since 1961. It caused heavy flooding in central and eastern China, affecting Hubei, Hunan, Anhui, and Jiangxi Provinces. Besides, in mid-July record high levels of water swelled thirty-three rivers, and the water level in 433 rivers surged above the flood control line. By July, nearly 55 million residents in twenty-seven out of thirty-one provinces in China were impacted by floods. Floods forced the relocation of 3.8 million people, caused the deaths or disappearance of 158 people, and inflicted damage of \$20.7 billion. For days, even the Yellow River in northern China experienced floods. In August 2020, Typhoon Bavi became the second typhoon to land in China's northeastern Liaoning Province since 1949, causing massive disruption. In Shenyang, the capital of Liaoning Province, 108 trains were halted out of safety concerns. In the province, water in fifty-one reservoirs swelled above the flood limit, and over 100,500 people had to be evacuated ( $\mathrm{Li} \& \mathrm{Wu}, 2020$ ). There are indications that the huge floods along the 
Yangtze and the typhoon caused a significant drop in crop output in central China and the northeast, China's biggest granaries. One academic study published in Environmental Research Letters in 2018 suggested that, if the temperature rose by 2 degrees, the historical 1-in-100 year high river level would occur once every twenty-five to thirty-five years in China. It is thus imperative for China to adhere to the objective of the 2015 Paris climate agreement by restricting warming to below 2 degrees Celsius (Pike 2020).

The third development is several proactive moves adopted by China toward carbon reduction. In September 2020, at a virtual summit meeting of the United Nations General Assembly, Xi announced China's goal to become carbon neutral before 2060. While this objective was undoubtedly ambitious, analysts suggest that moving away from coal power would remain a formidable task given that coal powers nearly two thirds of China's electricity, that 200 new coal power plants are being planned or built in China, and that 3.5 million workers in the coal-mining and power sector need to be properly resettled (Mallapaty 2020). In May 2021, China's government announced the establishment of an 'emissions peaking and carbon neutrality leading small group' (EPCNLSG), headed by the first Vice Premier Han Zhen. This LSG signalled China's determination to fulfil Xi's pledge. In June 2021, the Ministry of Environment and Ecology urged environmental authorities to tighten their approval of high-energy and high-emissions projects (CarbonBrief 2021b). While these two measures are welcome news, their effectiveness in curbing the strong growth in carbon emissions remains to be seen.

The first two aforementioned points suggest the same conclusion: it is in China's benefit as well as the interests of the rest of the world to maintain its commitments to fight climate change and to move toward a low-carbon economy, even in the wake of COVID-19 economic downturns. Failure to do so would roll back the gains in the previous years enabled by China's bold reduction in carbon intensity and its increase in carbon sinks through forestation. More importantly, China would feel the immediate and immense costs from its inaction or retreat from its climate commitments. The huge floods and Typhoon Bavi in China in 2020 served as a stern reminder of future devastation from extreme weather in China in the business-as-usual scenarios.

\section{Conclusion of analysis: the domestic explanation best explains the Chinese climate policy}

As we have seen, starting from a resistant stance during the long first period of 1990-2005, in the following decades China's climate change policy has become progressive and flexible. China has started to heed the harmful effects of climate 
change since 2006 and make global commitments to reduce carbon intensity and limit the growth in carbon emissions since 2009. Nevertheless, as detailed above, China's climate policy has experienced ups and downs. It also appeared to backtrack from its climate commitments twice under Xi, most noticeably during 2012-14 and to a lesser extent, during 2020-1.

As the previous analysis suggests and as summarised in Table 1, three sets of variables seem to explain to varying degrees the variation in China's climate change policy. The first variable is the nationalist claim in China's climate policy over the six periods. This claim usually maintains that China has the right to economic development and that China should be free from mandatory international monitoring. This variable seems to correlate well with China's climate policy in the first four periods. To be precise, the third period of 2009-11 among these four periods constitutes an outlier, when the explanatory power of the nationalist explanation seems partial, as China displayed a mixed position. On the one hand, China defended the nationalist position about rights to development and the CBDR principle. On the other hand, it started to make the first international commitments to climate action during 2009-11. The nationalist explanation does not fully explain China's stand and behaviour in the last two periods. During 2015-19, China adopted an international stand and argued for global action on the climate issue. During 2020-1, it maintained this position publicly, even though its domestic economic practice deviated from it.

The second variable is international demand, especially pressure from the developed world, chiefly Western Europe, that China should take decisive action and make a significant contribution to address climate change. This variable is derived from the liberal explanation. This variable seems to correlate with China's policy in four periods, namely, 1990-2005, 2006-8, 2009-11, and 2015-19. In the first period, international demand for China to act on climate change was modest, and the pressure mainly came from the United States which rejected the Kyoto Protocol. Partly thanks to weak international pressure, China could afford to take a resistant attitude in international climate talks. In the other three periods, international pressure on China had been intense, especially in the latter two periods. International pressure compelled China to step up its commitments first to reduce energy intensity during 2006-8, to cut carbon intensity during 2009-11, and to announce its target in 2015 to peak its carbon emissions in 2030. However, international pressure did not work its magic in the two periods, namely 2012-14 and 2020-1, where China seemed to substantially backtrack from its climate commitments.

The third set of variables that seem to correlate well with China's climate stance are those of the domestic political economy, especially the security of China's top leader and his concerns with economic growth. When the leader has not consolidated his power and feels insecure (A), or when he is greatly concerned with an apparent 
slowdown in the economic activities (B), China is likely to step back from its commitments to climate action. Type-A cases included Jiang who tried to establish himself as an able post-Deng leader during 1990-7, Hu who tried to consolidate his status as post-Jiang leader during 2003-5, and $\mathrm{Xi}$ who tried to consolidate his power during 2012-14 after he took over the reins from Hu. Type-B cases included the period 1990-7 when Jiang needed rapid economic growth to showcase his credentials as the post-Deng leader, the subsequent period of 1998-2001 when China tried to cope with the growth-decelerating effects of the Asian financial crisis, and the most recent period of 2020-1 when China tried to revive an economy hard hit by the COVID-19 pandemic. When the leader has consolidated his power, like Hu during 2006-8 and 2009-11 and Xi during 2015-19, or when high growth erased economic concerns, like Hu during 2006-8, China could take a relatively progressive stance on climate change (Table 1).

Overall, the domestic explanation seems able to account for China's climate policy in all six periods. In contrast, (neo-)realism/nationalism and liberalism could each explain China's climate stance in three out of six periods, and each could partially explain that in an additional period. This study sheds light on the critical factors, especially domestic political and economic considerations that shape China's climate policy, arguably the most consequential policy for the future of our planet. It thus showcases the intellectual appeal of a domestic explanation in helping us to comprehend the environmental and economic policy of a major power such as China. In addition, this study illuminates the strengths and especially limitations of the two mainstream theories (that is, the (neo-)realist/nationalist and liberal theories) in interpreting the climate policy of a major nation. The findings of this study could enhance our understanding of international politics and IPE of climate policy and could expand our intellectual toolkits in approaching climate policy by seriously heeding the domestic explanation. This insight will be indispensable for our intellectual input in combating climate change.

\section{A viable approach toward China in climate change}

The findings of this study reveal that in interacting with China regarding climate change it is important to address its domestic political and economic concerns. In the era of COVID-19 two issues seem to have become more salient for China's leaders. The first is to stimulate and sustain economic growth. This point was discussed earlier. The other is China's damaged external relations in the wake of the COVID-19 outbreak. The public and leaders in many nations, especially those in the developed world, widely perceived China's response to the novel coronavirus outbreak at the early stage as secretive and weak and regarded it as a critical cause for the rapid spread of the virus around the globe in the early months (PEW 2020). In addition to the 
COVID-19 rampage, international attention and controversies have surfaced in the recent few years regarding China's practice toward political freedom and human rights. As a result, the public impression of China in numerous advanced economies, most of them major trade partners and sources of foreign investment for China, has turned sour. A public opinion survey of seventeen advanced economies in the AsiaPacific and Western Europe in 2021 suggested that an average 88 per cent of the public viewed China negatively as they believed China did not respect the freedoms of its people. In addition, the majority (about two thirds) of the public in all but one of these economies preferred economic ties with the United States over those with China (PEW 2021). It is no exaggeration that China confronted the most strained ties with numerous nations in recent decades, especially in North America, Western Europe, Oceania, East Asia, South Asia, Eastern Europe, and Latin America. China's fractured political ties with these regions have resulted in China's diplomatic isolation unseen for decades.

To a large extent, China's sluggish economic growth is linked with its strained external ties, especially with its major trade partners. In order of importance, China's major trade partners include East Asia, Western Europe, North America, Southeast Asia, and South Asia. Many of these nations have already taken measures to reduce their reliance on trade, as well as investment and technological linkages with China. The subdued public enthusiasm in economic exchanges with China will only prompt these economies to take further cautionary measures in moving some of their trading or outsourcing activities away from China, thereby hurting China's economic growth.

Wierner (2008) urged enlightened pragmatism and domestic politics in engaging with China over climate action. Indeed, it is in China's political and economic interests to repair its strained external ties. Taking his recommendation for enlightened pragmatism this author proposes the following pragmatic approach of encouraging China to step forward toward climate action. The international community can and should make it clear to China that one of the most vital areas where it can rebuild its strained ties with the aforementioned regions is to take decisive actions in climate change. An improvement in China's ties with these regions will help China to partly regain its international standing which it had enjoyed for years before the COVID-19 outbreak. Furthermore, improved external ties and subsequent unhampered flow of trade and investment will give a strong external impetus to China's economic growth. In particular, China's firm commitment to climate action and the unambiguous demonstration of its actions are critical dimensions in its ties with the developed nations, particularly in Western Europe, East Asia, North America (including the United States in the wake of the presidential election), and Oceania. China's climate commitment is also of high importance for developing nations, many of which would suffer the most from the adverse effects of climate change. It would enable the global community including 
China to reduce or even evade impending calamitous events, such as severe heat, droughts, floods, storms, famines, massive and disruptive migration, and conflict. A firm climate commitment would enable China to gradually regain soft power and standing in the developing world. Driving home this point in global talks with China over climate change might trigger a favourable response from China at best, or dissuade China from taking too many regressive steps from its commitments to fight climate change at worst. The international community can and should respond favourably to China when it has heeded this advice and has indeed taken positive steps. While grievances between China and the rest of the world might not be easily brushed aside, both could and should work together on climate change to ensure a bright future for their respective populations and our planet.

\section{Acknowledgements}

The author would like to thank the two anonymous reviewers for their comments. He is responsible for the errors.

\section{References}

CarbonBrief (2021a), 'Analysis: China's Carbon Emissions Grow at Fastest Rate for More Than a Decade', 20 May. https://www.carbonbrief.org/analysis-chinas-carbon-emissions-grow-at-fastestrate-for-more-than-a-decade [accessed 6 July 2021].

CarbonBrief (2021b), 'China Briefing, 3 June 2021: New Climate "Leaders Group"; "Record-breaking" Electricity Consumption; "Artificial Sun"'. https://www.carbonbrief.org/china-briefing3-june-2021-new-climate-leaders-group-record-breaking-electricity-consumption-artificial-sun [accessed 6 July 2021].

Chen, G. (2012), 'China's Climate Policy', in China's Participation in Global Climate Politics (Abingdon, and New York, Routledge), Chapter 2.

Chen, Y. (2012), 'Performance Evaluation for Energy-conservation Targets in the Eleventh Five-Year Plan', in W. Wang, G. Zheng \& J. Pan (eds) China's Climate Change (London and New York, Routledge), 21-42.

Climate Action Tracker (2020), 'China'. https://climateactiontracker.org/countries/china/ [accessed 19 October 2020].

Dhakal, S. (2009), 'Urban Energy Use and Carbon Emissions from Cities in China and Policy Implications', Energy Policy, 37: 4208-19. https://doi.org/10.1016/j.enpol.2009.05.020

Dong, F., Yu, B. \& Hadachin, T. (2018), 'Drivers of Carbon Emission Intensity Change in China', Resources, Conservation \& Recycling, 129: 187-201. https://doi.org/10.1016/j.resconrec.2017.10.035

Elzen, M. den et al. (2016), 'Greenhouse Gas Emissions from Current and Enhanced Policies of China Until 2030: Can Emissions Peak Before 2030?', Energy Policy, 89: 224-36. https://doi.org/10.1016/j.enpol.2015.11.030

Gills, B. (2010), 'Going South: Capitalist Crisis, Systemic Crisis, Civilisational Crisis', Third World Quarterly, 31(2): 169-84. https://doi.org/10.1080/01436591003711926 
Gilpin, R. (1987), The Political Economy of International Relations (Princeton, NJ, Princeton University Press).

Gov.cn (2019), 'State Council Information Office Held a Press Conference Regarding the 2019 Annual Report on China's Policy and Actions in Response to Climate Change' (in Chinese), 17 November .http://www.gov.cn/xinwen/2019-11/27/content_5456146.htm [accessed 30 November 2020].

Guardian (2009), 'Ed Miliband: China Tried To Hijack Copenhagen Climate Deal', 20 December. https://www.theguardian.com/environment/2009/dec/20/ed-miliband-china-copenhagen-summit

Hardy, J. (2017), 'China's Place in the Global Divisions of Labour: An Uneven and Combined Development Perspective', Globalizations, 14(2): 189-201. https://doi.org/10.1080/14747731.2016.1200264

Heggelund, G. (2007), 'China's Climate Change Policy: Domestic and International Developments', Asian Perspective, 31(2), 155-91. https://doi.org/10.1353/apr.2007.0017

Hollingsworth, J. (2017), 'Looking Back at How China's Stance on Climate Change Shifted', South China Morning Post, 2 June. https://www.scmp.com/news/china/policies-politics/ article/2096690/looking-back-how-chinas-stance-climate-change-shifted

Independent (2009), 'China Stands Accused of Wrecking Global Deal: Nations Stunned by Tactics of World's Largest Polluter' (by M. McCarthy \& J. Owen), 20 December. https://www.independent. co.uk/climate-change/news/china-stands-accused-of-wrecking-global-deal-1845911.html

Keohane, R.O. (1984), After Hegemony: Cooperation and Discord in the World Political Economy (Princeton, NJ, Princeton University Press).

Keohane, R.O. \& Nye, J.S. (2012), Power and Interdependence, 4th edn (Boston, MA, and London, Longman).

Koleski, K. (2017), 'The 13th Five-Year Plan', the U.S.-China Economic and Security Review Commission staff research report, 14 February.

Lai, H. (2010), The Domestic Sources of China's Foreign Policy: Regimes, Leadership, Priorities, and Process (Abingdon and New York, Routledge).

Lai, H. (2021), 'The Rationale and Effects of China's Belt and Road Initiative: Reducing Vulnerabilities in Domestic Political Economy', Journal of Contemporary China, 30(128): 330-47. https://doi.org/10.1080/10670564.2020.1790896

Lai, H. \& Warner, M. (2015a), 'Managing China's Energy Sector: Between the Market and the State', Asia Pacific Business Review, 21(1): 1-9. https://doi.org/10.1080/13602381.2014.939887

Lai, H. \& Warner, M. (2015b), 'Transformation of China's Energy Sector: Trends and Challenges', Asia Pacific Business Review, 21(1): 147-53. https://doi.org/10.1080/13602381.2014.939900

Lewis, J. (2007), 'China's Strategic Priorities in International Climate Change Negotiations', The Washington Quarterly, 31(1): 155-74. https://doi.org/10.1162/wash.2007.31.1.155

Lewis, J. (2012), Green Innovation in China: China's Wind Power Industry and the Global Transition to a Low-carbon Economy (New York and Chichester, Columbia University Press). https://doi.org/10.7312/lewi15330

Li, H. \& Wu, Y. (2020), 'Rare Typhoon to Bring Rain, Gales to Liaoning', China Daily, 27 August.

Ma, X. et al. (2019), 'Carbon Emissions from Energy Consumption in China: Its Measurement and Driving Factors', Science of the Total Environment, 648: 1411-20. https://doi.org/10.1016/j.scitotenv.2018.08.183

Mallapaty, S. (2020), 'How China Could Be Carbon Neutral by Mid-century', Nature, 586: 482-3. https://doi.org/10.1038/d41586-020-02927-9

Mearsheimer, J.J. (2001), The Tragedy of Great Power Politics (New York and London, W.W. Norton).

New York Times (2009), 'Hu Jintao's Speech on Climate Change', 22 September . https://www.nytimes.com/2009/09/23/world/asia/23hu.text.html [accessed 13 October 2020.] 
O’Brien, R. \& Williams, M. (2016), Global Political Economy: Evolution and Dynamics 5th edn (London and New York, Palgrave Macmillan).

Our World in Data (2021), 'CO2 emissions'. https://ourworldindata.org/co2-emissions [accessed 22 June 2021].

PEW (2020), 'Unfavourable Views of China Reach Historic Highs in Many Countries: Majorities say China has Handled COVID-19 Outbreak Poorly,' Pew Research Centre, 6 October. https://www. pewresearch.org/global/2020/10/06/unfavorable-views-of-china-reach-historic-highs-in-manycountries/ [accessed 19 November 2021].

PEW (2021), 'Large Majorities Say China Does Not Respect the Personal Freedoms of Its People', Pew Research Centre, 30 June. https://www.pewresearch.org/globa1/2021/06/30/large-majorities-saychina-does-not-respect-the-personal-freedoms-of-its-people/ [accessed 5 July 2021].

Pike, L. (2020), 'China's Summer of Floods is a Preview of Climate Disasters to Come', Inside Climate News, 17 August. https://insideclimatenews.org/news/14082020/china-floods-climate-changeextreme-weather [accessed 30 October 2020].

Purdon, M. (2017), 'Neoclassical Realism and International Climate Change Politics: Moral Imperative and Political Constraint in International Climate Finance', Journal of International Relations and Development, 20: 263-300. https://doi.org/10.1057/jird.2013.5

REN21 (2020), 'Renewables 2020 Global Status Report' (Paris, REN21 Secretariat).

Smith, R. (2020), 'The Chinese Communist Party Is an Environmental Catastrophe: Political Ambitions Make China's Emissions Growth Inevitable Even as the Economy Falters', Foreign Policy, 27 July. https://foreignpolicy.com/2020/07/27/chinese-communist-party-environment-co2/ [accessed 31 October 2020].

Spracklen, D.V. (2016), 'China's Contribution to Climate Change', Nature, 531: 310-1. https://doi.org/10.1038/531310a

Stensdal, I. (2014), 'Chinese Climate-change Policy, 1988-2013: Moving On Up', Asian Perspective, 38(1): 111-35. https://doi.org/10.1353/apr.2014.0004

Thomson, E. \& Boey, A. (2015), 'The Role of Oil and Gas in China’s Energy Strategy: An Overview', Asia Pacific Business Review, 21(1): 10-12. https://doi.org/10.1080/13602381.2014.939890

Victor, D.G. (2006), 'International Cooperation on Climate Change: Numbers, Interests and Institutions', Global Environmental Politics, 6(3): 90-103. https://doi.org/10.1162/glep.2006.6.3.90

Wang, W., Zheng, G. \& Pan, J. (eds) (2012), China's Climate Change (London and New York, Routledge).

Wendt, A. (1999), Social Theory of International Politics (Cambridge, Cambridge University Press). https://doi.org/10.1017/CBO9780511612183

Wiener, J.B. (2008), 'Climate Change Policy and Policy Change in China', UCLA Law Review, 55: 1805-26.

Woetzel, J., Zhang, H., Krishnan, M., Henderson, K. \& Lam, G. (2020), 'Leading the Battle Against the Climate Change: Actions for China', McKinsey Global Institute, 12 June. https://www. mckinsey.com/business-functions/sustainability/our-insights/leading-the-battle-againstclimate-change-actions-for-china

World Resources Institute (2014), 'The History of Carbon Dioxide Emissions'. http://www.wri.org/blog/2014/05/history-carbon-dioxide-emissions.

World Resources Institute (2017), ‘Top 10 Emitters'. https://www.wri.org/blog/2017/04/ interactive-chart-explains-worlds-top-10-emitters-and-how-theyve-changed

Xinhua Net (2020), 'Our Nation Has Attained Significant Achievements in Coping with Climate Change and Furthering Low Carbon Development' (in Chinese), 27 September. http://www.xinhuanet.com/2020-09/27/c_1126549274.htm [accessed 30 October 2020]. 
Xu, M. \& Stanway, D. (2020), 'China's Post-Pandemic Economic Stimulus Puts 2020 Climate Pledges at Risk', Reuters, 20 May. https://uk.reuters.com/article/us-health-coronavirus-china-climateanal/chinas-post-pandemic-economic-stimulus-puts-2020-climate-pledges-at-risk-idUKKBN22W0YW [accessed 31 October 2020].

Yu, H. (2012), 'The Influential Factors of China's Regional Energy Intensity and Its Spatial Linkages: 1988-2007,' Energy Policy, 45: 583-93. https://doi.org/10.1016/j.enpol.2012.03.009

Zhang, X.-P. \& Cheng, X.-M. (2009), 'Energy Consumption, Carbon Emissions, and Economic Growth in China', Ecological Economics, 68: 2706-12. https://doi.org/10.1016/j.ecolecon.2009.05.011

Zhang, Z., Qu, J. \& Zeng, J. (2009), Wenshi qiti paifang: Kexue pingjia yu jianpai zhengce (Greenhouse Gas Emissions: Scientific Assessment and Policy for Emissions Reduction) (Beijing, Kexue chubanshe).

Zhang, X., Karplus, V.J., Qi,T., Zhang, D. \& He, J. (2016), 'Carbon Emissions in China: How Far Can New Efforts Bend the Curve?', Energy Economics, 54: 388-95.

https://doi.org/10.1016/j.eneco.2015.12.002

To cite the article: Hongyi Lai (2021), 'The evolution of China's climate change policy: international and domestic political economy and a strategy for working with China', Journal of the British Academy, 9(s10): 69 -98.

DOI https://doi.org/10.5871/jba/009s10.069

Journal of the British Academy (ISSN 2052-7217) is published by

The British Academy, 10-11 Carlton House Terrace, London, SW1Y 5AH

www.thebritishacademy.ac.uk 